\title{
Obesity and Stroke: Does the Paradox Apply for Stroke?
}

\author{
Gabriel A Quiñones-Ossa, $\mathrm{MD}^{1,2}$, Carolina Lobo, $\mathrm{MD}^{1}$, Ezequiel Garcia-Ballestas, $\mathrm{MD}^{2,3}$, \\ William A Florez, $\mathrm{MD}^{2}$, Luis Rafael Moscote-Salazar, $\mathrm{MD}^{2,3}$, Amit Agrawal, $\mathrm{MCh}^{4}$ \\ ${ }^{1}$ Faculty of Medicine, University El Bosque, Bogota, Colombia \\ ${ }^{2}$ Consejo Latinoamericano de Neurointensivismo (CLaNi), Cartagena, Colombia \\ ${ }^{3}$ Centro de Investigaciones Biomedicas (CIB), Faculty of Medicine, University of Cartagena, Cartagena, Colombia \\ ${ }^{4}$ Department of Neurosurgery, All India Institute of Medical Sciences, Madhya Pradesh, India
}

Historically, obesity has been identified as one of the most important risk factors for developing cardiovascular diseases including stroke; however, a theory called "The Obesity Paradox" has been recently considered. The paradoxical theory is that obese or overweight patients (according to body mass index score) can have better outcomes compared to leaner or malnourished patients. The paradox was initially discovered in patients with heart failure. The purpose of this manuscript was to investigate whether this paradox also applies to stroke patients, according to information available in the current literature.

Key Words: Obesity; Cerebrovascular disease; Stroke; Body mass index

\section{INTRODUCTION}

Worldwide, stroke is the second leading cause of death and obesity is the second leading preventable cause of death. Obesity is a risk factor for multiple cardiovascular diseases, such as coronary disease, coronary death, congestive heart failure, and stroke. ${ }^{1,2}$ In China, stroke is the main cause of major disability and mortality. ${ }^{3}$ During the last 40 years, the world prevalence of obesity has nearly tripled. By 2016, the World Health Organization reported 38\% of men and $40 \%$ of female patients (1.9 billion) were overweight, and $11 \%$ and $14 \%$ (600 million) were obese, respectively. ${ }^{4}$ In the United States, annual medical spending has considerably increased due to excess weight and was estimated to reach nearly USD 80 billion in 1998 and USD 147 billion in 2008..$^{5}$ Moreover, between 2000 and 2005, the medical cost for obesity-related illness was estimated to be more than 200 billion, equivalent to more than a fifth of the national health expenditure. ${ }^{6}$ Therefore, the need to elucidate the relationship between obesity and most diseases is progressively increasing. There is very little evidence addressing cerebrovascular diseases and obesity, other than the relative risk of occurrence of the disease. Studies are more focused on stroke prevention than on prognosis in obese patients. Pathophysiological mechanisms underlying the effect of obesity on stroke remain unclear and controversial. There is a recent theory called "The Obesity Paradox" that states that patients with an elevated body mass index (BMI) might present better clinical

\section{Correspondence to:}

Ezequiel Garcia-Ballestas, MD

Centro de Investigaciones Biomedicas (CIB), Faculty of Medicine, University of Cartagena, Cra. 50 \#24-120, Cartagena 130001, Colombia Tel: +573192256956

E-mail:ezegames@hotmail.es

Received: March 25, 2020

Revised: November 4, 2020 Accepted: November 11, 2020

Copyright $\odot 2021$ Korean Society of Interventional Neuroradiology

This is an Open Access article distributed under the terms of the Creative Commons Attribution Non-Commercial License (http://creativecommons.org/licenses/by-nc/4.0) which permits unrestricted non-commercial use, distribution, and reproduction in any medium, provided the original work is properly cited.

pISSN 2093-9043 eISSN 2233-6273 
outcomes after a heart failure, although the information regarding its relation with stroke is scarce. The objective of this manuscript is to provide an overview on whether there is a relationship between the obesity paradox and stroke, along with its neurointerventional implications, by reviewing the current literature.

\section{THE CURRENT GLOBAL PROBLEM OF STROKE AND OBESITY}

Stroke is an alteration in cerebral perfusion due to multiple causes and is the second leading cause of death and disability worldwide. Its frequency has increased recently in lowand middle-income countries and decreased in high-income countries, ${ }^{7-12}$ and its incidence doubles in individuals older than 55 years of age. ${ }^{13}$ The diagnosis is made based on neurological signs and symptoms that provide evidence on the affected vessel and corresponding brain region. ${ }^{10,14-16}$ Usually, the symptoms include unilateral extremity weakness, numbness, visual alterations (e.g., blurred vision, diplopia, or binocular blindness), alteration in speech, vertigo, hemiballismus, and alien hand syndrome. ${ }^{14}$ Depending on injury magnitude, tissue compromise, and opportune medical management, patients can present with multiple lethal complications that may lead to unfavorable outcomes. ${ }^{17,18}$ There are multiple risk factors for stroke development like arterial hypertension, hypercholesterolemia, diabetes mellitus, cardiopathy, tobacco or excessive alcohol consumption, environmental air pollution, high-risk diet, and obesity. ${ }^{12,14,27,19-26}$

Obesity is the second leading cause of preventable death (after tobacco) worldwide and is considered a public health problem with a doubled prevalence since the 1980s, due to the globalization of its risk factors and an exponential

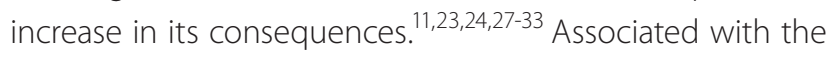
high prevalence are the changes in diet, sugar intake, chemicals added to products in food treatment, bigger portion size, low/inadequate physical activity, bad eating habits, more processed food, and foods with higher caloric content. $8,28,33$ Altogether, they have contributed to the weight gain in the population that lead to the fact that obesity is currently considered a pandemic. ${ }^{8,28,34}$ Obesity is diagnosed as a BMI $>30 \mathrm{~kg} / \mathrm{m}^{2}$ (calculated by the patient's weight in kilograms divided by the squared height in meters). ${ }^{20,22,29,30,35,36} \mathrm{How}$ ever, it is important to consider the world regions and countries, as the measurement can change somewhat. ${ }^{8,12,28,37}$

\section{BMI AND OBESITY}

The current problem with the BMI measure is that it does not give a precise idea about body composition, which affects health risks of excess weight such as the proportion of bodyweight and the distribution of fat. ${ }^{23,32,38-40} \mathrm{BMI}$ has been criticized because it does not differentiate fatness, obesity, and adiposity measurement. 11,29,32,39,40 Other methods, including waist circumference and central and peripheral fat mass, have also been proposed for the diagnosis; still, $\mathrm{BMI}$ continues to be used for the classification of obesity. ${ }^{23,32,41}$ Individuals are classified as overweight if their BMI is between $25 \mathrm{~kg} / \mathrm{m}^{2}$ and $30 \mathrm{~kg} / \mathrm{m}^{2}$, obese if it is between 30 and $40 \mathrm{~kg} / \mathrm{m}^{2}$, and morbidly obese if it is greater than $40 \mathrm{~kg} / \mathrm{m}^{2}{ }^{40,42,43} \mathrm{BMl}$ is not used for children and adolescents from 2 to 18 years; instead, it is recommended that a percentile scale based on the child's sex and age be used. In this population, overweight is defined as a BMI in the $85^{\text {th }}$ to $94^{\text {th }}$ percentile, and obesity is a BMI at or above the $95^{\text {th }}$ percentile. $^{42,43}$ In the INTERHEART study, BMI was related to the risk of myocardial infarction, but this relation was weaker than that of abdominal obesity (waist-to-hip ratio or WHR), with BMI becoming non-significant with the inclusion of WHR in the multivariate model. ${ }^{44}$ In addition, a study in 32 countries, whose objective was to determine the risk factors of stroke (INTERSTROKE study), showed a weaker association with the WHR ${ }^{45}$ However, it is known that each unit of $\mathrm{BMl}$ is independently associated with a $6 \%$ increase in the relative risk of stroke. ${ }^{46}$ Even though there are other measurements than BMI, they do not show an obesity paradox, but a linearly increased mortality association is evidenced. ${ }^{40}$

\section{THE OBESITY PARADOX}

As we previously mentioned, obesity predisposes an increased risk of suffering cardiovascular and systemic diseases, such as stroke and other diseases. ${ }^{29,33,34,47-49}$ It is associated with premature mortality; and, in multiple studies, a higher risk of cardiovascular disease incidence has been demonstrated in underweight adults or just overweight (but not obese) patients. As a result, there is no clear evidence of a higher prevalence or incidence of stroke in those with an obesity diagnosis. ${ }^{37,47}$ The "Obesity paradox theory" says that patients with high BMI could have a better prognosis than leaner patients (lean paradox) regarding clinical outcomes in 
those with cardiovascular diseases. ${ }^{22,25,30,40,50}$ This means that even when obesity leads to higher complications and risk of suffering from multiple diseases and complications, high adiposity can present a protective role against infections and, regarding stroke, better mortality and outcomes. ${ }^{11,23,25,34,47}$
Some studies show that for every 5-unit increase in BMI above $25 \mathrm{~kg} / \mathrm{m}^{2}$, overall mortality increases by $29 \%$, vascular mortality by $41 \%$, and diabetes-related mortality by $210 \% .^{21,51}$ In 2001, Horwich et al. ${ }^{26}$ coined the term "Obesity Paradox" to describe these findings correlating an increase in BMI with

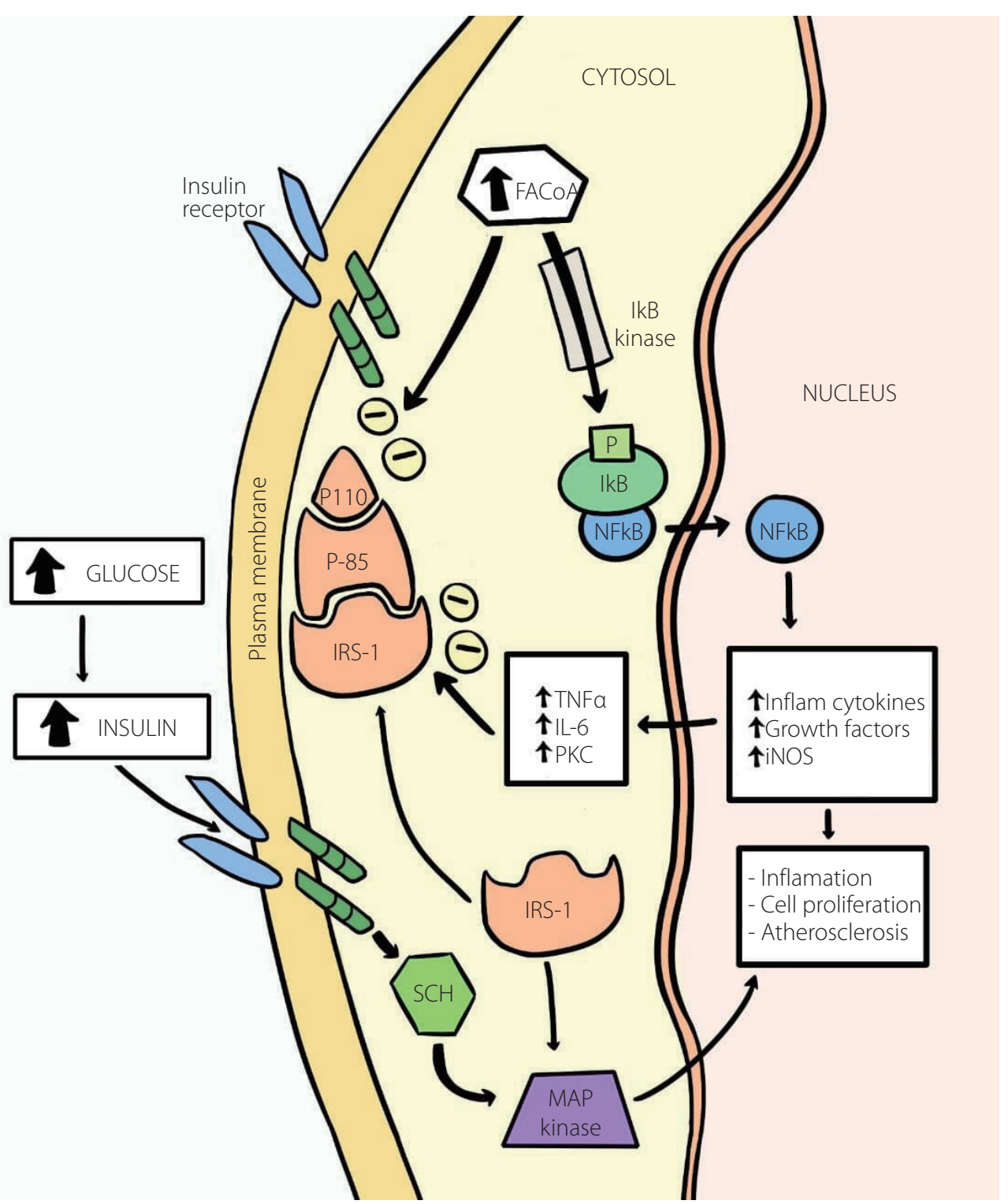

Fig. 1. Increased activity of IkB/NFkB as the basis of the chronic inflammation and insulin resistance in type 2 diabetes. Intracellular fatty acyl-CoA levels found in insulin resistance and lipotoxicity, in correlation to the subsequent activation of the enzyme lkB kinase (via inflammatory factors such as fatty acyl-CoAs), will phosphorylate IkB, causing the release of NFkB (upon the polyubiquitination and degradation of IkB), which enters the nucleus where it is responsible for inflammation, cell proliferation and atherogenesis by the stimulation of inflammatory cytokines, growth factors, and iNOS, which in turn will stimulate TNFa, IL-6, and PKC, which will impede insulin signaling by serine phosphorylation of IRS-1 ultimately, causing insulin resistance. Therefore, the increased activity of IkB/NFkB will not only instigate inflammation but also further aid and boost atherogenesis. The MAP kinase pathway is responsible for the insulin-stimulated glucose impaired metabolism and for this reason, related to cardiovascular diseases. FACoA, Fatty acyl-CoA; IkB, Inhibitor kB; IL1 and IL6, Interleukins 1 and 6; IRS, Insulin Receptor Substitute 1; MAP, Mitogen-Activated Protein; NFkB, Nuclear factor kB; NO, Nitric Oxide; NOS, Nitric Oxide Synthase; PI3K, Phosphoinositide 3-kinase; PKC, Protein Kinase C; SCH, Src homology 2 domain; TNFa, Tumor Necrosis Factor alpha; Inflam, Inflammatory. Adapted and modified from the article of Yazici and Sezer (Adv Exp Med Bio/ 2017;960:277-304). ${ }^{56}$ 
better prognosis and clinical evolution of patients with heart failure. ${ }^{22,23,30,52}$ Two years later, Lavie et al. ${ }^{53}$ found that every $1 \%$ increment in body fat percentage will correspond with a 13\% reduction in cardiovascular events. ${ }^{25,30}$ The "fat but fit" phenomenon was proposed to explain those obese patients without metabolic derangements whose outcomes were unfavorable. ${ }^{54}$

The obesity paradox can be explained by the protective effect of a major endocrine organ known as adipose tissue, 22,47 which secretes soluble TNF-alpha-receptors and neutralizes the impact of tumor necrosis factor alpha (TNF alpha) in the human biological system and inflammatory responses. ${ }^{23,26,30,47}$ Overweight and obese patients have higher lipoproteins and lipids serum levels, and these play an important role in detoxifying and binding lipopolysaccharides and are related to inflammatory cytokines cascade blocking. Further, these molecules impede the inflammatory state after a stroke episode. ${ }^{30,32,47}$ Knowing that inflammation and immune mechanisms are risk factors and outcome predictors in stroke, is important to consider that obesity has an inflammatory component and is known as a low-grade chronic inflammatory condition due to the C-reactive protein, TNF alpha, soluble intracellular adhesion molecule-1 and interleukins (the proinflammatory markers are low in the obese compared to infectious situations but remain elevated in longer periods). ${ }^{12,20,30-32}$

\section{ADIPOSITY AND LIPOTOXICITY IN STROKE}

Adipocytes produce adipokines, and these hormones play a protective role in the myocardium, but pro-inflammatory cytokines like interleukin-1b and 18, TNF-alpha and some others, lead to diastolic dysfunction. ${ }^{21-23,26,29,30,32}$ Lipotoxicity (a term originally used to describe the destructive effects of excess fat accumulation on glucose metabolism) causes functional impairments in several metabolic pathways, both in adipose tissue and peripheral organs, like the liver, heart, pancreas, and muscle. They also play an important role in insulin resistance and pancreatic beta-cell dysfunction. ${ }^{26}$

The lipid peroxidation and hydrolysis of free fatty acids (FFA) in the liver and vascular endothelium, along with high levels in patients with obesity, promote FFA transport to peripheral tissues and increments of total body fat. This generates a higher concentration of adipokines and various hormones that activate the pathogenesis base pro-inflammatory pathway of atherosclerosis and its chronic complications (stroke, myocardial infarction, etc.). These hormones block second messengers favoring insulin resistance (Fig. 1). 21,22,26,27,52,55,56 In addition to being found in adipose tissue, lipids are also found in liposomes, which are small cytoplasmic organelles in proximity to the mitochondria in many types of cells. Furthermore, accumulation of excess lipid intermediates (e.g., ceramides) in some adipose tissues can lead to lipotoxicity

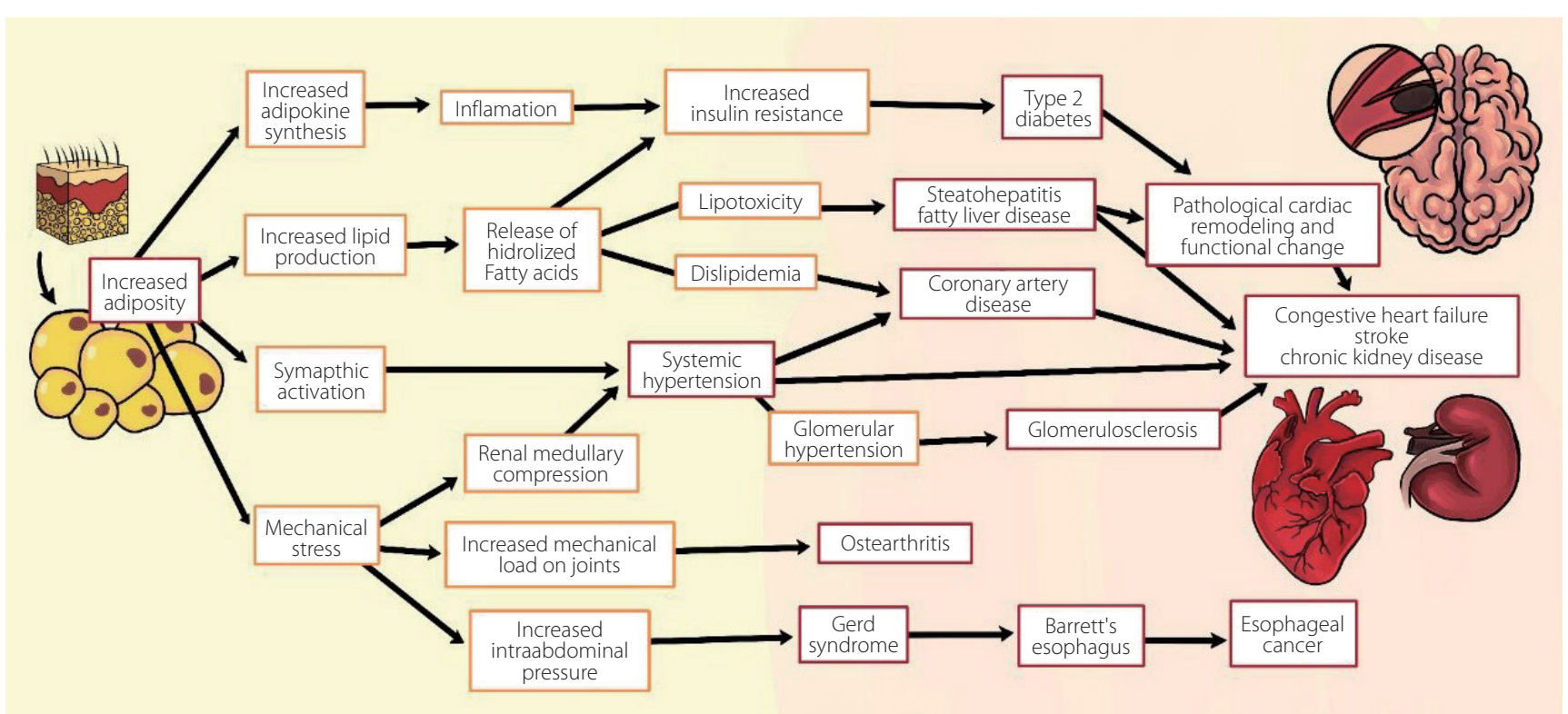

Fig. 2. The adiposity and lipotoxicity in chronic disease. Adapted and modified from the article of Heymsfield and Wadden (N Engl J Med 2017;376:254-266). ${ }^{57}$ 
with cellular dysfunction and apoptosis in all types of cells (including neurons and neuro-vasculature cells), and this is the base for the development of neurodegenerative and cerebrovascular diseases. ${ }^{26}$ The excess production of fatty acids increases adipose tissue and pro-inflammatory products resulting from lipid peroxidation, together with atherosclerosis, which leads to an increase in vascular resistance and a state of chronic sympathetic hyperactivity. This influences the pathogenesis of many of chronic diseases. ${ }^{47,52,55}$ Fig. 2 shows various pathways of chronic disease development that involve adiposity and lipotoxicity. ${ }^{57}$

\section{CURRENT EVIDENCE FOR THE OBESITY PARADOX AND STROKE RELATIONSHIP}

As mentioned before, obesity predisposes a risk for developing vascular diseases like stroke. ${ }^{7,36,47,58}$ Further, it has been established that for a BMI greater than 20 , an increase by every unit adds to the ischemic stroke risk by $5 \% .{ }^{7,47}$ The relation between stroke risk increase in obese patients is related to the amount of adipose tissue and a repository of inflammatory cells that lead to subsequent atherosclerosis promoted by hyperglycemia and insulin resistance. ${ }^{7,21,31}$ In some studies, it has been shown that obese patients could present with mild ischemic strokes due to small vessel occlusion and have better functional outcomes, which means those patients have a lower mortality risk. ${ }^{9,58}$ Table 1 presents additional studies regarding the beneficial or favorable relationship of the obesity paradox with stroke..$^{59-65}$

However, some studies indicate that for obesity class III (40 to $49.9 \mathrm{~kg} / \mathrm{m}^{2}$ ) the paradox is no longer applicable due to the $U$ or $\mathrm{J}$ shaped effect. ${ }^{30}$ Further, there is a clear association between BMI-related mortality and this effect. ${ }^{40}$ In this case, these effects show that depending on the "nutritional status" at the extreme points, the paradox (that is the reason why it is a $U$ or J shaped effect) is not useful, as each extreme point (morbid obesity or malnourished) has a higher risk of incidence, unfavorable outcomes, and mortality. The intermediate point or low curve will be obesity. By this, it could be presumed that being obese does not necessarily lead to a higher stroke incidence. ${ }^{20,23,34,37,39,40,47,66}$ Some studies have reported a "protective effect" on stroke outcomes in obese patients. Higher BMI has been related to lower long-term mortality and higher improved outcomes after a stroke episode when compared to patients with a normal BMI. ${ }^{20}$

More recently, in patients suffering from stroke and intracerebral hemorrhage, the evidence is less clear regarding $\mathrm{BMI}$ and its association with complications and outcomes in aneurysmal subarachnoid hemorrhage (SAH). In the TEMPiS

Table 1. Additional studies regarding the beneficial or favorable relationship of the obesity paradox for stroke in humans

\begin{tabular}{|c|c|c|c|}
\hline Authors & Year & $\begin{array}{l}\text { Number of } \\
\text { patients }\end{array}$ & Results \\
\hline Kim et al. ${ }^{59}$ & 2011 & 1,356 & $\begin{array}{l}\text { Non-obese patients' survivors after an intracranial hemorrhage episode live less and } \\
\text { concluded that obesity is not associated with greater mortality after intracranial bleed- } \\
\text { ing after a stroke episode }\end{array}$ \\
\hline Vemmos et al. ${ }^{60}$ & 2011 & 2,785 & $\begin{array}{l}\text { Compared to normal-weight patients, obese or overweight patients present reduced } \\
\text { long-term mortality after a stroke episode }\end{array}$ \\
\hline Doehner et al. ${ }^{27}$ & 2013 & 1,521 & $\begin{array}{l}\text { Overweight or obese patients present a better survival rate compared to normal or } \\
\text { underweight patients and less fatal outcomes after stroke }\end{array}$ \\
\hline Hassan et al. ${ }^{61}$ & 2013 & 81,579 & $\begin{array}{l}\text { Compared to non-obese patients, the obese ones who were treated with intravenous } \\
\text { rt-PA after an acute ischemic stroke presented less mortality }\end{array}$ \\
\hline Skolarus et al. ${ }^{62}$ & 2014 & 1,791 & $\begin{array}{l}\text { Patients with an obesity class } 2 \text { diagnosis present a lower mortality risk than mor- } \\
\text { bid-obesity patients }\end{array}$ \\
\hline Andersen and Olsen ${ }^{63}$ & 2015 & 29,326 & Readmission for recurrent stroke and mortality post-stroke were lower in obese patients \\
\hline Hoffman et al. ${ }^{64}$ & 2019 & 123,415 & $\begin{array}{l}\text { Obesity and morbidity patients with intracranial hemorrhage had reduced in-hospi- } \\
\text { tal mortality rates and obesity (not morbid obesity) patients had a reduced rate in } \\
\text { non-routine hospital discharge }\end{array}$ \\
\hline Persaud et al. ${ }^{65}$ & 2019 & 99,212 & $\begin{array}{l}\text { For obese patients who suffer a hemorrhagic stroke, there was a lower probability of } \\
\text { in-hospital deaths compared to the non-obese }\end{array}$ \\
\hline
\end{tabular}

rt-PA, recombinant tissue-plasminogen activator. 
(Telemedical Project for Integrative Stroke Care) trial study where clinical outcomes (mortality and good neurological prognosis) were evaluated and grouped according to BMI, mortality was significantly lower in obese patients (all BMI $30 \mathrm{~kg} / \mathrm{m}^{2}$ ) than in patients with normal weight (hazard ratio: 0.70; 95\% confidence interval: 0.50-0.98). ${ }^{27,55}$ In conclusion, The trial study showed that overweight patients with acute stroke or TIA (Transient Ischemic Attack) compared to lean or malnourished patients presents a better outcome and less dependency. ${ }^{27}$

A systematic review by Oesch et al. ${ }^{47}$ evaluated 25 studies in which 299,700 patients participated, and found 10 of 12 studies (162,921 patients) reported significantly fewer mortality rates in stroke patients with higher BMl values. In total, 7 of 9 studies (92,718 patients) showed a favorable effect of excess body weight on non-fatal outcomes (good clinical outcome, recurrence of vascular events). In 6 studies (85,042 patients), contradictory results after intravenous thrombolysis were seen; however, several methodological limitations were observed in a major part of the studies (observational study design, inaccuracy of BMI in reflecting obesity, lacking body weight measurement, selection bias, survival bias). ${ }^{22,47}$

Some other studies also reported an association between the paradox and stroke. A study by Rodríguez-Castro et al. ${ }^{31}$ measured obese and non-obese patients with stroke and showed that obese patients present better neurological impairment recovery but do not present worse clinical evolution after stroke compared to non-obese patients, Kim et al. ${ }^{67}$ showed an obesity paradox evidenced after 90 days post-stroke where obese patients showed less mortality than leaner patients.

Very few studies regarding obese patients and the paradox relation with stroke reach an adequate level of evidence. For example, Persaud et al. ${ }^{65}$ in 2019 showed that obese patients with intracranial hemorrhage had a better survival rate during the in-hospital stay, and they credited this result to statins intake and its pleiotropic effect with respective anti-inflammatory and anti-thrombotic properties that might reduce the infarcted area and increase survival rates. Regarding the relation of BMI to outcomes after a surgical procedure, the results might be a little controversial, and this may be because of the difference in the treatment and its frequency. ${ }^{68}$

\section{NEUROINTERVENTIONAL IMPLICATIONS}

While endovascular implications and the obesity paradox are well-depicted in cardiovascular disease, ${ }^{69}$ in cerebrovascular diseases the evidence is scarce. Obesity Class I (BMI from 30 to 34.9) has been shown to reduce the risk of stroke and mortality following a carotid endarterectomy procedure due to occlusion and stenosis of the carotid artery. Even though these results could not be corroborated with the lean paradox because of not reaching significance in the analysis, only Class I obesity had better outcomes, but the increase in BMI was associated with a higher risk of cardiac arrest. ${ }^{70}$ To reinforce this theory, the MR CLEAN trial underwent a post hoc analysis ( $n=366$ ) and concluded that higher BMI improved functional outcomes, lowered mortality, and reduced recurrence of stroke progression after endovascular treatment of acute stroke due to large vessel occlusion. ${ }^{71}$ Overweight and obese patients were also associated with a better 3-month recovery after stroke. ${ }^{72}$ However, these results are not always reproducible as seen in Bouslama et al. ${ }^{73}(n=926)$, which could not find an association between BMl and outcomes after mechanical thrombectomy due to large vessel occlusive acute ischemic stroke. Also, Chen et al..$^{74}(n=248)$ reported that metabolic syndrome (which measures obesity according to waist circumference) was associated with increased risk of unfavorable functional outcome at 90 days in ischemic stroke treated with endovascular treatment, but was not associated with mortality. However, this study had a small sample size and metabolic derangement ascribed to metabolic syndrome had a stronger influence on outcomes more than pure obesity. Therefore, to correctly apply the obesity paradox, the "fat but fit" phenomenon should be also taken into account. Branscheidt et al. ${ }^{75}$ showed no association of obesity and outcomes in ischemic stroke treated by thrombolysis. However, the small sample size has to be highlighted as well. The lean paradox has to be included in the obesity paradox concept as well. In other series, Rinaldo et al. ${ }^{68}$ reported that depending on the procedure (clipping or coiling) when treating an acute SAH, the outcome could change according to BMI values. An elevated BMI was associated with an increased odds of an unfavorable outcomes when the patient was treated with a clipping procedure but with a decreased odds when treated with the coiling procedure. This study also established that the increased and decreased odds were related to hypodensities detection (infarction zones) after the treatment, which could be associated with 
a mechanism mediated by the patient BMI that could affect the outcome prognosis, as the coiling procedure in patients with high BMI was associated with a reduced incidence of hypodensities. ${ }^{68}$ The study of Dasenbrock et al. ${ }^{76}$ concluded that adiposity might not interfere with the patient's outcome after a SAH. Hughes et al. ${ }^{55}$ performed an analysis of patients with an elevated $\mathrm{BMI}$ that were treated with clipping or coiling procedures and found that there was no difference in the functional outcomes after the procedure. The retrospective analysis of Platz et al. ${ }^{77}$ did not found any correlation between $\mathrm{BMI}$ and the outcome after a SAH. Also, according to the results of the study made by Schultheiss, obesity might not be important regarding the outcome variables in patients who needed cranial surgery. ${ }^{78}$ These statements were also evidenced by some other studies. ${ }^{79,80}$ Even the use of statins to modify the metabolism of cholesterol has not shown any benefit unlike patients receiving statins after endovascular treatment for atherosclerotic lesions in coronary, peripheral, and cerebrovascular circulations. The patients receiving statins after a flow diverter did not benefit from the same. ${ }^{81,82}$ Despite the evidence, further studies are needed to clearly outline recommendations for performing endovascular treatment in obese patients.

\section{CONCLUSIONS}

Stroke incidence is increasing and represents a high socio-economic impact on healthcare costs. ${ }^{83}$ This implies a loss of life quality and daily life activities due to its severe sequelae. The management of stroke in obese patients is a challenge. We must carry out the individualization of established treatments, even while the Obesity Paradox makes it look like a good protective factor. Still, the management of risk factors (for stroke and obesity) is related to a higher reduction in incidence and recurrence for stroke.? Obesity is widely accepted and known as a cardio-cerebrovascular risk factor, so it is recommended that adequate body weight control (BMl $<25 \mathrm{~kg} / \mathrm{m}^{2}$ ) is maintained as primary prevention, as well as a secondary prevention. ${ }^{9}$ Due to the U-shaped effect, we can assume that the Obesity Paradox is only applicable to Class I and II, but it is important to bear in mind the importance of treatment and prevention of obesity, especially to avoid getting into class III or greater. ${ }^{30,84}$ Distinguishing between pure obesity and a metabolic derangement is essential in interpreting the results since this is clearly proven to pro- duce poor outcomes, as seen with the metabolic syndrome. Furthermore, the integration of concepts should be properly applied during the design of a study. The Obesity Paradox should always coincide with the fat but fit phenomenon and the lean paradox. Regarding the pure Obesity Paradox, there is a lot of controversial information on this topic; however, studies that support the theory of the Obesity Paradox present many methodological and quality limitations. For the moment, there is not a clear relationship between the Obesity Paradox in stroke patients, and quality studies are needed to answer this question, especially if a relationship between stroke and obesity is investigated. As a matter of fact, higher sample studies regarding neurosurgical intervention and obesity are needed to establish stronger evidence, regardless of whether there is or is not a correlation between the paradox and stroke.

\section{Fund}

None.

\section{Ethics Statement}

This study waived approval of the institutional ethics committee.

\section{Conflicts of Interest}

The authors have no conflicts to disclose.

\section{Author Contributions}

Concept and design: $E G, A A$, and GAQ. Writing the article: $E G$, $G A Q$, and CL. Critical revision of the article: $L R M, W A F, E G$, and $C L$. Final approval of the article: $E G$ and $A A$.

\section{ORCID}

Gabriel A Quiñones-Ossa: https://orcid.org/0000-0003-1495-4633

Carolina Lobo: https://orcid.org/0000-0002-5638-8628

Ezequiel Garcia-Ballestas: https://orcid.org/0000-0002-7075-8007

William A Florez: https://orcid.org/0000-0002-6951-1277

Luis Rafael Moscote-Salazar: https://orcid.org/0000-0002-4180-6962

Amit Agrawal: https://orcid.org/0000-0002-3287-5448

\section{REFERENCES}

1. Hubert HB, Feinleib M, McNamara PM, Castelli WP. Obesity as an independent risk factor for cardiovascular disease: a 26-year follow-up of participants in the Framingham heart study. Circu- 
lation 1983;67:968-977

2. Yatsuya H, Yamagishi K, North KE, Brancati FL, Stevens J, Folsom AR; ARIC Study Investigators. Associations of obesity measures with subtypes of ischemic stroke in the ARIC study. J Epidemiol 2010;20:347-354

3. Wu S, Wu B, Liu M, Chen Z, Wang W, Anderson CS, et al.; China Stroke Study Collaboration. Stroke in China: advances and challenges in epidemiology, prevention, and management. Lancet Neurol 2019;18:394-405

4. World Health Organization (WHO). Obesity and overweight [Internet]. Geneva: WHO [cited 2020 Oct 28]. Available from: https://www.who.int/news-room/fact-sheets/detail/obesity-and-overweight

5. Finkelstein EA, Trogdon JG, Cohen JW, Dietz W. Annual medical spending attributable to obesity: payer-and service-specific estimates. Health Aff (Millwood) 2009;28:w822-w831

6. Cawley J, Meyerhoefer $C$. The medical care costs of obesity: an instrumental variables approach. J Health Econ 2012;31:219-230

7. Guzik A, Bushnell C. Stroke epidemiology and risk factor management. Continuum (Minneap Minn) 2017;23:15-39

8. Hruby A, Hu FB. The epidemiology of obesity: a big picture. Pharmacoeconomics 2015:33:673-689

9. Kim Y, Kim CK, Jung S, Yoon BW, Lee SH. Obesity-stroke paradox and initial neurological severity. J Neurol Neurosurg Psychiatry 2015;86:743-747

10. Johnson W, Onuma O, Owolabi M, Sachdev S. Stroke: a global response is needed. Bull World Health Organ 2016;94:634-634A

11. Lavie CJ, Arena R, Alpert MA, Milani RV, Ventura HO. Management of cardiovascular diseases in patients with obesity. Nat Rev Cardiol 2018;15:45-56

12. Guo Y, Yue XJ, Li HH, Song ZX, Yan HQ, Zhang P, et al. Overweight and obesity in young adulthood and the risk of stroke: a meta-analysis. J Stroke Cerebrovasc Dis 2016;25:2995-3004

13. Ovbiagele B, Nguyen-Huynh MN. Stroke epidemiology: advancing our understanding of disease mechanism and therapy. Neurotherapeutics 2011;8:319-329

14. Hankey GJ. Stroke. Lancet 2017;389:641-654

15. Díez-Tejedor E, del Brutto O, Alvarez Sabín J, Muñoz M, Abiusi G; Sociedad Iberoamericana de Enfermedades Cerebrovasculares. [Classification of the cerebrovascular diseases. Iberoamerican Cerebrovascular diseases Society]. Rev Neurol 2001;33:455-464 Spanish

16. Cassella CR, Jagoda A. Ischemic stroke: advances in diagnosis and management. Emerg Med Clin North Am 2017;35:911-930

17. Wang P, Wang Y, Zhao X, Du W, Wang A, Liu G, et al. In-hospital medical complications associated with stroke recurrence after initial ischemic stroke: a prospective cohort study from the China National Stroke Registry. Medicine (Baltimore) 2016;95:e4929

18. Jordán J, Ikuta I, García-García J, Calleja S, Segura T. Stroke pathophysiology: management challenges and new treatment advances. J Physiol Biochem 2007;63:261-277

19. Morales-Plaza CD, Aguirre-Castañeda C, Machado-Alba JE. [Predictors of stroke mortality in the Hospital Universitario San Jorge of Pereira (Colombia)]. Salud Uninorte 2016;32:56-64 Spanish

20. Haley MJ, Lawrence CB. Obesity and stroke: can we translate from rodents to patients? J Cereb Blood Flow Metab 2016;36:2007-2021

21. Letra L, Sena C. Cerebrovascular disease: consequences of obesity-induced endothelial dysfunction. In: Letra L, Seiça R. Obesity and brain function, Cham: Springer, 2017;163-189

22. Carbone S, Lavie CJ, Arena R. Obesity and heart failure: focus on the obesity paradox. Mayo Clin Proc 2017;92:266-279

23. Clark AL, Fonarow GC, Horwich TB. Obesity and the obesity paradox in heart failure. Prog Cardiovasc Dis 2014;56:409-414

24. Mitchell AB, Cole JW, McArdle PF, Cheng YC, Ryan KA, Sparks MJ, et al. Obesity increases risk of ischemic stroke in young adults. Stroke 2015:46:1690-1692

25. Brzecka A, Ejma M. Obesity paradox in the course of cerebrovascular diseases. Adv Clin Exp Med 2015;24:379-383

26. Horwich TB, Fonarow GC, Hamilton MA, MacLellan WR, Woo $M A$, Tillisch $J H$. The relationship between obesity and mortality in patients with heart failure. J Am Coll Cardiol 2001;38:789-795

27. Doehner W, Schenkel J, Anker SD, Springer J, Audebert HJ. Overweight and obesity are associated with improved survival, functional outcome, and stroke recurrence after acute stroke or transient ischaemic attack: observations from the TEMPiS trial. Eur Heart J 2013;34:268-277

28. Bhurosy $T$, Jeewon R. Overweight and obesity epidemic in developing countries: a problem with diet, physical activity, or socioeconomic status? ScientificWorldJournal 2014;2014:964236

29. Elagizi A, Kachur S, Lavie CJ, Carbone S, Pandey A, Ortega FB, et al. An overview and update on obesity and the obesity paradox in cardiovascular diseases. Prog Cardiovasc Dis 2018;61:142-150

30. Parto P, Lavie CJ, Arena R, Bond S, Popovic D, Ventura HO. Body habitus in heart failure: understanding the mechanisms and clinical significance of the obesity paradox. Future Cardiol 2016;12:639-653

31. Rodríguez-Castro E, Rodríguez-Yáñez M, Arias-Rivas S, Santamaría-Cadavid M, López-Dequidt I, Hervella P, et al. Obesity paradox in ischemic stroke: clinical and molecular insights. Trans/ Stroke Res 2019;10:639-649 
32. Horwich TB, Fonarow GC, Clark AL. Obesity and the obesity paradox in heart failure. Prog Cardiovasc Dis 2018;61:151-156

33. GBD 2015 Obesity Collaborators, Afshin A, Forouzanfar MH, Reitsma MB, Sur P, Estep K, et al. Health effects of overweight and obesity in 195 countries over 25 years. N Engl J Med 2017:377:13-27

34. Dangayach NS, Grewal HS, De Marchis GM, Sefcik RK, Bruce R, Chhatlani A, et al. Does the obesity paradox predict functional outcome in intracerebral hemorrhage? J Neurosurg 2018;129:1125-1129

35. Forlivesi S, Cappellari M, Bonetti B. Obesity paradox and stroke: a narrative review. [published online ahead of print Mar 2, 2020] Eat Weight Disord 2020

36. Vilahur G, Ben-Aicha S, Badimon L. New insights into the role of adipose tissue in thrombosis. Cardiovasc Res 2017;113:10461054

37. Bosello O, Donataccio MP, Cuzzolaro M. Obesity or obesities? Controversies on the association between body mass index and premature mortality. Eat Weight Disord 2016;21:165-174

38. Ashwell M, Mayhew L, Richardson J, Rickayzen B. Waist-toheight ratio is more predictive of years of life lost than body mass index. PLoS One 2014;9:e103483

39. Wang S, Ren J. Obesity paradox in aging: from prevalence to pathophysiology. Prog Cardiovasc Dis 2018;61:182-189

40. Antonopoulos AS, Tousoulis D. The molecular mechanisms of obesity paradox. Cardiovasc Res 2017;113:1074-1086

41. Engin A. The definition and prevalence of obesity and metabolic syndrome. Adv Exp Med Biol 2017;960:1-17

42. Apovian CM. Obesity: definition, comorbidities, causes, and burden. Am J Manag Care 2016;22(7 Suppl):s176-s185

43. Uribe AG, Gómez FR, Muñoz NJM, Bernal GB, Hoyos JLO, Tovar YG, et al. [Guía de práctica clínica: para la prevención, diagnóstico y tratamiento del sobrepeso y la obesidad en adultos. Sistema general de seguridad social en salud - Colombia. Guía completa. guía no. 52]. Bogotá: Ministerio de Salud y Protección Social; 2016 Spanish

44. Yusuf S, Hawken S, Ounpuu S, Dans T, Avezum A, Lanas F, et al.; INTERHEART Study Investigators. Effect of potentially modifiable risk factors associated with myocardial infarction in 52 countries (the INTERHEART study): case-control study. Lancet 2004;364:937-952

45. O'Donnell MJ, Chin SL, Rangarajan S, Xavier D, Liu L, Zhang H, et al.; INTERSTROKE investigators. Global and regional effects of potentially modifiable risk factors associated with acute stroke in 32 countries (INTERSTROKE): a case-control study. Lancet 2016;388:761-775
46. Kurth T, Gaziano JM, Berger K, Kase CS, Rexrode KM, Cook NR, et al. Body mass index and the risk of stroke in men. Arch Intern Med 2002;162:2557-2562

47. Oesch L, Tatlisumak T, Arnold M, Sarikaya H. Obesity paradox in stroke - myth or reality? A systematic review. PLoS One 2017;12:e0171334

48. Semler MW, Self WH, Wanderer JP, Ehrenfeld JM, Wang L, Byrne DW, et al.; SMART Investigators and the Pragmatic Critical Care Research Group. Balanced crystalloids versus saline in critically ill adults. N Engl J Med 2018;378:829-839

49. Rautalin I, Kaprio J, Korja M. Obesity paradox in subarachnoid hemorrhage: a systematic review. [published online ahead of print Oct 29, 2019] Neurosurg Rev 2019

50. Lavie CJ, De Schutter A, Parto P, Jahangir E, Kokkinos P, Ortega FB, et al. Obesity and prevalence of cardiovascular diseases and prognosis-the obesity paradox updated. Prog Cardiovasc Dis 2016:58:537-547

51. Ng M, Fleming T, Robinson M, Thomson B, Graetz N, Margono C, et al. Global, regional, and national prevalence of overweight and obesity in children and adults during 1980-2013: a systematic analysis for the Global Burden of Disease Study 2013. Lancet 2014;384:766-781

52. Triviño L, Ávila JC, Ramírez-Vélez R. [The paradox of obesity and its relationship to cardiorespiratory fitness in patients with heart failure]. Rev Colomb Cardiol 2015;22:218-223 Spanish

53. Lavie CJ, Osman AF, Milani RV, Mehra MR. Body composition and prognosis in chronic systolic heart failure: the obesity paradox. Am J Cardiol 2003;91:891-894

54. Ortega FB, Ruiz JR, Labayen I, Lavie CJ, Blair SN. The fat but fit paradox: what we know and don't know about it. Br J Sports Med 2018;52:151-153

55. Hughes JD, Samarage M, Burrows AM, Lanzino G, Rabinstein AA. Body mass index and aneurysmal subarachnoid hemorrhage: decreasing mortality with increasing body mass index. World Neurosurg 2015;84:1598-1604

56. Yazıcı D, Sezer H. Insulin resistance, obesity and lipotoxicity. Adv Exp Med Biol 2017;960:277-304

57. Heymsfield SB, Wadden TA. Mechanisms, pathophysiology, and management of obesity. N Engl J Med 2017;376:254-266

58. Wohlfahrt P, Lopez-Jimenez F, Krajcoviechova A, Jozifova M, Mayer O, Vanek J, et al. The obesity paradox and survivors of ischemic stroke. J Stroke Cerebrovasc Dis 2015;24:1443-1450

59. Kim BJ, Lee SH, Ryu WS, Kim CK, Lee J, Yoon BW. Paradoxical longevity in obese patients with intracerebral hemorrhage. Neurology 2011;76:567-573

60. Vemmos K, Ntaios G, Spengos K, Savvari P, Vemmou A, Pappa 
T, et al. Association between obesity and mortality after acute first-ever stroke: the obesity-stroke paradox. Stroke 2011;42:3036

61. Hassan AE, Chaudhry SA, Jani V, Grigoryan M, Khan AA, Adil $M M$, et al. Is there a decreased risk of intracerebral hemorrhage and mortality in obese patients treated with intravenous thrombolysis in acute ischemic stroke? J Stroke Cerebrovasc Dis 2013;22:545-549

62. Skolarus LE, Sanchez BN, Levine DA, Baek J, Kerber KA, Morgenstern LB, et al. Association of body mass index and mortality after acute ischemic stroke. Circ Cardiovasc Qual Outcomes 2014;7:64-69

63. Andersen KK, Olsen TS. The obesity paradox in stroke: lower mortality and lower risk of readmission for recurrent stroke in obese stroke patients. Int J Stroke 2015;10:99-104

64. Hoffman H, Jalal MS, Furst T, Chin LS. The obesity paradox in spontaneous intracerebral hemorrhage: results from a retrospective analysis of the nationwide inpatient sample. Neurocrit Care 2020;32:765-774

65. Persaud SR, Lieber AC, Donath E, Stingone JA, Dangayach NS, Zhang $X$, et al. Obesity paradox in intracerebral hemorrhage. Stroke 2019;50:999-1002

66. Lavie CJ, De Schutter A, Milani RV. Body composition and the obesity paradox in coronary heart disease: can heavier really be healthier? Heart 2015;101:1610-1611

67. Kim BJ, Lee SH, Jung KH, Yu KH, Lee BC, Roh JK; For Korean Stroke Registry investigators. Dynamics of obesity paradox after stroke, related to time from onset, age, and causes of death. Neurology 2012;79:856-863

68. Rinaldo L, Hughes JD, Rabinstein AA, Lanzino G. Effect of body mass index on outcome after aneurysmal subarachnoid hemorrhage treated with clipping versus coiling. J Neurosurg 2018;129:658-669

69. Sharma A, Vallakati A, Einstein AJ, Lavie CJ, Arbab-Zadeh A, Lopez-Jimenez $F$, et al. Relationship of body mass index with total mortality, cardiovascular mortality, and myocardial infarction after coronary revascularization: evidence from a meta-analysis. Mayo Clin Proc 2014;89:1080-1100

70. Jackson RS, Black JH 3rd, Lum YW, Schneider EB, Freischlag JA, Perler BA, et al. Class I obesity is paradoxically associated with decreased risk of postoperative stroke after carotid endarterectomy. J Vasc Surg 2012;55:1306-1312

71. Pirson FAV, Hinsenveld WH, Staals J, de Greef BTA, van Zwam WH, Dippel DWJ, et al.; on behalf of MR CLEAN investigators. The effect of body mass index on outcome after endovascular treatment in acute ischemic stroke patients: a post hoc analysis of the MR CLEAN trial. Cerebrovasc Dis 2019;48:200-206

72. Zhao L, Du W, Zhao X, Liu L, Wang C, Wang Y, et al. Favorable functional recovery in overweight ischemic stroke survivors: findings from the China National Stroke Registry. J Stroke Cerebrovasc Dis 2014;23:e201-e206

73. Bouslama M, Perez HJ, Barreira CM, Haussen DC, Grossberg JA, Belagaje SR, et al. Body mass index and clinical outcomes in large vessel occlusion acute ischemic stroke after endovascular therapy. Interv Neurol 2020;8:144-151

74. Chen Z, Su M, Li Z, Du H, Zhang S, Pu M, et al. Metabolic syndrome predicts poor outcome in acute ischemic stroke patients after endovascular thrombectomy. Neuropsychiatr Dis Treat 2020;16:2045-2052

75. Branscheidt M, Schneider J, Michel P, Eskioglou E, Kaegi G, Stark $R$, et al. No impact of body mass index on outcome in stroke patients treated with IV thrombolysis BMI and IV thrombolysis outcome. PLoS One 2016;11:e0164413.

76. Dasenbrock HH, Nguyen MO, Frerichs KU, Guttieres D, Gormley WB, Ali Aziz-Sultan M, et al. The impact of body habitus on outcomes after aneurysmal subarachnoid hemorrhage: a Nationwide Inpatient Sample analysis. J Neurosurg 2017;127:36-46

77. Platz J, Güresir E, Schuss P, Konczalla J, Seifert V, Vatter H. The impact of the body mass index on outcome after subarachnoid hemorrhage: is there an obesity paradox in $\mathrm{SAH}$ ? A retrospective analysis. Neurosurgery 2013;73:201-208

78. Schultheiss KE, Jang YG, Yanowitch RN, Tolentino J, Curry DJ, Lüders J, et al. Fat and neurosurgery: does obesity affect outcome after intracranial surgery? Neurosurgery 2009;64:316-326

79. Tawk RG, Grewal SS, Heckman MG, Navarro R, Ferguson JL, Starke EL, et al. Influence of body mass index and age on functional outcomes in patients with subarachnoid hemorrhage. Neurosurgery 2015;76:136-141

80. Kagerbauer SM, Kemptner DM, Schepp CP, Bele S, Rothörl RD, Brawanski AT, et al. Elevated premorbid body mass index is not associated with poor neurological outcome in the subacute state after aneurysmal subarachnoid hemorrhage. Cent Eur Neurosurg 2010;71:163-166

81. Brinjikji W, Cloft H, Cekirge S, Fiorella D, Hanel RA, Jabbour P, et al. Lack of association between statin use and angiographic and clinical outcomes after pipeline embolization for intracranial aneurysms. AJNR Am J Neuroradio/ 2017;38:753-758

82. Salem MM, Maragkos GA, Enriquez-Marulanda A, Ascanio L, Ravindran K, Alturki AY, et al. Statin therapy and diabetes do not affect aneurysm occlusion or clinical outcomes after pipeline embolization device treatment: a preliminary study. World Neurosurg 2018;120:e525-e532 
83. Ekker MS, Boot EM, Singhal AB, Tan KS, Debette S, Tuladhar AM, et al. Epidemiology, aetiology, and management of ischaemic stroke in young adults. Lancet Neurol 2018;17:790-801

84. Lavie CJ, McAuley PA, Church TS, Milani RV, Blair SN. Obesity and cardiovascular diseases: implications regarding fitness, fatness, and severity in the obesity paradox. J Am Coll Cardiol 2014;63:1345-1354 